„FOLIA BIBLIOLOGICA” (2018), VOL. LX

DOI: $10.17951 / \mathrm{fb} .2018 .60 .15-36$

Monika Janusz-Lorkowska

Wydział Dziennikarstwa, Informacji i Bibliologii

Uniwersytet Warszawski

https://orcid.org/0000-0002-4411-6537

\title{
BADANIA CZYTELNICTWA W POLSCE W KONTEKŚCIE WYBRANYCH PARADYGMATÓW NAUK SPOŁECZNYCH
}

\begin{abstract}
Streszczenie: Artykuł poddaje rozważaniom dwa rodzaje badań czytelnictwa w Polsce: ilościowe, przeprowadzane przez Bibliotekę Narodową, oraz jakościowe, zrealizowane przez pracowników naukowych Wydziału Dziennikarstwa, Informacji i Bibliologii Uniwersytetu Warszawskiego na zlecenie Fundacji Centrum Cyfrowe. Nie są analizowane ich wyniki. Interesujące są metody i cele tych badań w kontekście filozoficznym - w kierunku wybranych metateorii, dzięki którym są możliwe. Podjęto próbę wskazania i krótkiego opisania niektórych paradygmatów nauk społecznych, które stoją za różniącymi się od siebie pod każdym względem projektami badawczymi podejmującymi odmiennie ten sam temat - czytelnictwo.
\end{abstract}

Słowa kluczowe: czytelnictwo, badania jakościowe, badania ilościowe, paradygmaty naukowe, paradygmaty nauk społecznych

\section{Research on Reading Practices in Poland in the Context of Selected Paradigms of Social Sciences}

\begin{abstract}
The article deals with two types of reading research in Poland: quantitative, carried out by the National Library, and qualitative, made by the academic staff of the Faculty of Journalism, Information and Bibliology of the University of Warsaw, commissioned by the Centrum Cyfrowe Foundation. Their results are not analyzed. Interesting are the methods and goals of these research in a philosophical context - in the context of selected metatheses. An attempt is made here to indicate and briefly describe some of the paradigms of social sciences, which stand behind these research projects being different from each other in every aspect, but, however, regarding the same topic - reading.
\end{abstract}

Keywords: readership, reading, qualitative research, quantitative research, scientific paradigms, paradigms of social sciences 
W opublikowanym w październiku 2015 roku wywiadzie w związku z przeprowadzanymi przez Bibliotekę Narodową badaniami czytelnictwa Roman Chymkowski - kierownik Pracowni Badań Czytelnictwa Instytutu Książki i Czytelnictwa Biblioteki Narodowej, stwierdził: „Mamy czym się chwalić. Nikt w skali świata nie prowadzi takich badań równie systematycznie, tak poważnie traktując zarówno ich metodologię, jak i uzyskane za ich pomocą wyniki. Można powiedzieć, że nasze badania czytelnictwa wraz z komentarzami, które wokół nich narosły, są pierwszorzędnym źródłem wiedzy nie tylko o dynamice naszej kultury, ale również o naszej zbiorowej samowiedzy"'. Słowa te stały się inspiracją do podjęcia refleksji nad ustaleniem, czy i jakie paradygmaty nauk społecznych stoją za realizowanymi w Polsce badaniami czytelnictwa, czy i jak determinują one takie badania.

Dla realizacji tego celu w artykule wzięto pod uwagę dwa najnowsze badania czytelnictwa w Polsce. Pierwsze to tzw. ilościowe pomiary opublikowane pod hasłem Stan czytelnictwa $w$ Polsce w 2016 roku ${ }^{2}$, o których pisał R. Chymkowski. Drugie to badania jakościowe Jak czytaja Polacy?3. Zostały one zrealizowane niemal równoległe z wyżej wymienionymi, czyli w latach 2015-2016, przez zespół pracowników naukowych Wydziału Dziennikarstwa, Informacji i Bibliologii Uniwersytetu Warszawskiego na zlecenie Fundacji Centrum Cyfrowe.

W Polsce jest realizowanych wiele różnorodnych badań związanych z nawykami czytelniczymi Polaków ${ }^{4}$. Dwa powyższe przykłady wybrano nie bez powodu. Interesujące są - w świetle zarysowanego tematu artykułu - nie tyle ich wyniki, co sposoby, jakimi je przeprowadzono, a także powody i cele, dla których je zre-

1 M. Majewska, Czytanie jako praktyka społeczna (rozmowa o badaniach czytelnictwa), „Krytyka Polityczna” Warszawa, [online]. Dostępny w World Wide Web: http://krytykapolityczna.pl/kultura/ czytaj-dalej/badanie-czytelnictwa-roman-chymkowski-wywiad/ [dostęp: 20.05.2018].

2 Stan czytelnictwa w Polsce w 2016 roku, [online]. Dostępny w World Wide Web: http://www. bn.org.pl/download/document/1492678784.pdf [dostęp: 15.05.2018] (raport z badań z roku 2017 w momencie pisania niniejszego tekstu nie był jeszcze gotowy).

3 M. Kisilowska, M. Paul, M. Zając, Jak czytaja Polacy?/Przełączamy społeczeństwo na cyfrowe, Warszawa 2016, [online]. Dostępny w World Wide Web: https://centrumcyfrowe.pl/wp-content/ uploads/2016/06/Jak-czytają-Polacy-raport-końcowy.pdf [dostęp: 17.05.2018].

4 Zob. np.: M. Jurewicz, Czytanie ze zrozumieniem. Uwarunkowania rodzinne, Warszawa 2010, [online]. Dostępny w World Wide Web: http://www.publio.pl/files/samples/7a/fd/f6/92563/Czytanie_ ze_zrozumieniem_Uwarunkowania_rodzinne_demo.pdf [dostęp: 17.05.2018]; K. Wodniak, Badanie tempa i techniki czytania studentów informacji naukowej i bibliotekoznawstwa, Toruń 2008, [online]. Dostępny w World Wide Web: http://www.home.umk.pl/ tsb/sites/default/files/numer1/wodniak. pdf [dostęp: 17.05.2018]; Ogólnopolskie badania czytelnictwa prasy realizowane przez Kantar Polska S.A., [online]. Dostępny w World Wide Web: http://www.pbc.pl/rynek-prasowy/; Badania efektów czytania dzieciom od urodzenia prowadzone przez Ośrodek Ewaluacji na zlecenie Fundacji „ABC XXI - Cała Polska czyta dzieciom”, [online]. Dostępny w World Wide Web: https://mail.google.com/ mail/u/1/?tab=wm\#search/ahastokarz\%40interia.pl/162cd64fc2943e00?projector=1\&messagePartId=0.5 [dostęp: 17.05.2018]. 
alizowano. Badania te prezentują bowiem dwa kompletnie odmienne podejścia metodologiczne w kwestii naukowej obserwacji czytania i czytelnictwa w Polsce. Jak to możliwe/dlaczego jest to możliwe? Komu/czemu to zawdzięczamy? Na podstawie m.in. metod badawczych, jakie w nich zastosowano, podjęta zostanie próba dostrzeżenia paradygmatów naukowych z nimi związanych.

Ustalenie, jakie paradygmaty naukowe kryją się za badaniami społecznego zasięgu książki w Polsce, należy rozpocząć od dookreślenia jednego z tytułowych przedmiotów badań, jaką jest „czytelnictwo”. Niezbędna jest również definicja pojęcia „paradygmat”. W kolejnym kroku można będzie podjąć próbę określenia, w jakie paradygmaty naukowe wpisują się przytoczone badania.

\section{Czytanie i czytelnictwo - w stronę definicji pojęć}

O to, czy wiedzę o czytelnictwie można traktować jako samodzielną dyscyplinę naukową, pytał teoretycznie m.in. Jacek Wojciechowski. W argumentacji za tym stwierdzeniem stwierdził, że czytelnictwo posiada własny przedmiot badań, wyspecjalizowane techniki analizy i konkretny dorobek ${ }^{5}$. Przyznaje jednak, że badacze czytelnictwa niemal wszystko przejęli z innych nauk: teorie, hipotezy oraz metodykę badań, dlatego należałoby raczej mówić o księgoznawczym (bibliologicznym) ujęciu czytelnictwa. Przy czym w procesie konstytuowania się perspektywy obserwacji zjawisk czytelniczych należy pamiętać, że „w praktyce badawczej utrwaliły się ujęcia socjologiczne, psychologiczne oraz pedagogiczne - w czym nie ma żadnych sprzeczności, nie są to bowiem stanowiska alternatywne"6.

Miejsce czytelnictwa w klasyfikacji nauk cechuje rozbieżność stanowisk, a co za tym idzie - brak jednoznacznego podejścia w kwestii zakresu przedmiotu badań. Pisała o tym w latach 80 . XX wieku Alina Wajda w klasycznym podręczniku Metodyka i organizacja czytelnictwa:

Nie bez znaczenia pozostaje fakt, że dotychczasowa wiedza o czytelnictwie tkwi w sferze badań empirycznych [...]. Badaniom empirycznym zarzuca się zbyt mechaniczne i uproszczone przenoszenie przyrodniczych technik badawczych na zjawiska społeczne, wyróżniające się jednostkowością i niepowtarzalnością ludzkich zachowań i problemów - niewymierna złożoność wewnętrznej sfery psychiki ludzkiej wymaga złożonych, introspekcyjnych metod i technik badawczych ${ }^{7}$.

${ }^{5}$ J. Wojciechowski, Czytelnictwo, Kraków 2000, s. 5.

${ }^{6}$ Ibidem, s. 7.

7 A. Wajda, Metodyka i organizacja czytelnictwa, Warszawa 1983, s. 3-4. 
Obecnie badania związane z czytelnictwem są zaliczane w Polsce do tzw. kultury książki i informacji ${ }^{8}$, analizowanej w obrębie bibliologii ${ }^{9}$ W ujęciu polskich badaczy (K. Migoń, B. Koredczuk, D. Grygrowski i E. Zybert ${ }^{10}$ bibliologia jako nauka bada procesy tworzenia, obiegu i konsumpcji książki oraz dokumentów pisanych, skutki tych procesów, a także instytucje oraz ludzi, którzy w nich uczestniczą. Łączy tak autonomiczne pojęcia, jak księgarstwo, bibliografia, bibliotekarstwo, edytorstwo i typografia, informacja naukowa, czytelnictwo. U swego zarania była nauką historyczną, dziś - interdyscyplinarną, a wraz z rozwojem nauk o komunikowaniu przez wielu badaczy zaliczaną właśnie do nich. Mimo swej interdyscyplinarności bibliologia według polskiej urzędowej klasyfikacji nauk jest póki co (zgodnie z rozporządzeniem Ministra Nauki i Szkolnictwa Wyższego z 8 sierpnia 2011 ${ }^{11}$ ) zaliczana do nauk humanistycznych. W projekcie rozporządzenia Ministra Nauki i Szkolnictwa Wyższego z 31 lipca 2018 roku jest z kolei umieszczona wraz z informatologią oraz naukami o mediach i naukami o poznaniu i komunikacji społecznej w dziedzinie nauk społecznych ${ }^{12}$. Przyjmując - zgodnie z regułą mówiącą, że w klasyfikacji nauk podstawowym kryterium jest przedmiot badań, czyli kryterium ontologiczne - że przedmiotem badań jest stricte czytelnictwo, należy uznać, że w przypadku czytelnictwa mamy do czynienia nie z nauką humanistyczną, lecz z nauką społeczną. Zarówno bowiem tzw. czytelnik „zbiorowy”, jak i „indywidualny”"13 rozpatrywany

${ }^{8}$ K. Migoń, Bibliologia - nauka o kulturze książki, „Nauka” 2005, nr 2, s. 49-57.

9 Przytaczane przez Sabinę Cisek międzynarodowe badania Alvina Schradera i Lloyda Housera dowiodły, że w obiegu naukowym istnieje aż 445 definicji bibliologii i naukowej informacji. S. Cisek, Filozoficzne aspekty informacji naukowej, Kraków 2002, s. 62.

${ }_{10}$ K. Migoń, Bibliologia - nauka o kulturze ksiązki, „Nauka” 2005, nr 2, s. 49-57; B. Koredczuk, Początki teorii bibliologii, Wrocław 2005; D. Grygrowski, E. Zybert, Bibliologia, biblioteki, bibliotekarze, Warszawa 2005.

11 Rozporządzenie Ministra Nauki i Szkolnictwa Wyższego z dnia 8 sierpnia 2011 w sprawie obszarów wiedzy, dziedzin nauki i sztuki oraz dyscyplin naukowych i artystycznych, [online]. Dostępny w World Wide Web: http://www.bip.nauka.gov.pl/g2/oryginal/2013_05/bc84c9b55b1826a8b0b936f7b41fe8ce.pdf [dostęp: 15.05.2018].

12 Projekt ten na etapie pisania niniejszego artykułu był konsultowany. Dostęp do projektu rozporządzenia Ministra Nauki i Szkolnictwa Wyższego w sprawie dziedzin nauki i dyscyplin naukowych oraz dyscyplin artystycznych z datą 31 lipca 2018, [online]. Dostępny w World Wide Web: https://www.ujk.edu.pl/webujk/files/2018/Rozporzadzenie_wraz_z_uzasadnieniem_ MinistraNaukiiSzkolnictwaWyzszego_dziedziny_naukiidyscyplin_naukowych_oraz_dyscyplin_artystycznych.pdf [dostęp: 20.08.2018].

${ }_{13}$ M. Skwarnicki, Czytelnictwo i metody jego badania, [w:] Problemy czytelnictwa $w$ wielkich miastach. Krajowa Konferencja Bibliotekarska w Warszawie (2-4 czerwca 1958): referaty, przebieg obrad, red. S. Tazbir, Warszawa 1960. Za pojęciami Skwarnickiego - czytelnik „indywidualny” i czytelnik „zbiorowy” - można wywieść różnicę pomiędzy czytaniem a czytelnictwem (czytanie jest działalnością indywidualną, a czytelnictwo zbiorową). Więcej o czytelniku w kontekście badań na- 
jest kolejno z perspektywy socjologicznej i z perspektywy psychologicznej, czyli z perspektywy nauk, które są zaliczane do nauk społecznych ${ }^{14}$.

„Czytanie - wbrew zdroworozsądkowemu rozumieniu - jest nie tylko praktyką indywidualną, ale też społeczną, więc nie możemy myśleć o promocji czytelnictwa, abstrahując od wymiaru społecznego tej praktyki kulturowej”"15 - stwierdził cytowany na wstępie R. Chymkowski. Czym jest praktyka społeczna? Według Jerzego Kmity, "praktyką społeczną jest ogół czynności subiektywno-racjonalnych, tworzących łącznie diachroniczną strukturę funkcjonalną: utrzymującą stan globalny polegający na odtwarzaniu, połączonym zwykle z przetwarzaniem rozwojowym [...] aktualnych warunków obiektywnych owej praktyki" ${ }^{16}$. Badacz wymienił wiele społecznych praktyk, m.in. komunikacyjne, obyczajowe, religijne, naukowe. Każda jest według niego regulowana „subiektywnie w skali społecznej przez pewien zespół przekonań powszechnie w danej społeczności respektowanych i należących do jej świadomości społecznej” ${ }^{17}$. Warto w tym miejscu wyjaśnić różnicę między praktyką społeczną i indywidualną, przytaczając słowa Michała Wendlanda: „można powiedzieć, że praktyki indywidualne to poszczególne działania [...], praktyki społeczne są swego rodzaju »zbiorami« czy »sumami« poszczególnych praktyk indywidualnych, czyli działań. A więc całość złożona z wszystkich działań danego typu (czyli praktyk indywidualnych) jest określoną praktyką społeczną" ${ }^{18}$. Z powyższych względów paradygmaty stojące za kluczowymi dla niniejszego artykułu polskimi badaniami czytelnictwa będę charakteryzować w kontekście nauk społecznych ${ }^{19}$.

ukowych w: I. Socha, Czytelnik w polskiej myśli bibliologicznej, [w:] Czytanie, czytelnictwo, czytelnik, red. A. Żbikowska-Migoń, współ. A. Łuszpak, Wrocław 2011, s. 25-44.

14 Rozporządzenie Ministra Nauki i Szkolnictwa Wyższego z dnia 8 sierpnia 2011....

15 M. Majewska, op. cit.

16 J. Kmita, O kulturze symbolicznej, Warszawa 1982, s. 30.

17 Ibidem, s. 63.

${ }_{18}$ M. Wendland, Praktyki komunikacyjne jako praktyki społeczne w ujęciu historycznym, [w:] Historia idei komunikacji, red. M. Wendland, Poznań 2015, s. 99.

19 Należy wyraźnie zaznaczyć, że mamy obecnie do czynienia z pewnym zwrotem (narzuconym również niejako „odgórnie”), w zaliczaniu bibliologii do nauk społecznych, dotąd sytuowanej w naukach humanistycznych (poza tym wszelkie klasyfikacje nauk mają przede wszystkim charakter utylitarny i cechują się zmiennością). Z refleksji nad czytelnictwem z pewnością nie można całkowicie (chociażby z powodu ograniczeń objętościowych niniejszego artykułu i skoncentrowaniu się na czytaniu jako czynności społecznej) wyłączyć perspektywy humanistycznej. Wychodząc poza samą czynność czytania, należy pamiętać, że owa czynność koncentruje się na przedmiocie: na książce, wypowiedzi w formie drukowanej czy cyfrowej, a badania owego przedmiotu to już domena nauk humanistycznych. 


\section{Paradygmat}

Jak zaznaczył Bartosz Sławecki, „pojęcie paradygmatu wiąże się z określonym, spójnym wewnętrznie zbiorem przekonań filozoficznych dotyczących natury rzeczywistości społecznej i natury badań naukowych" ${ }^{20}$. Termin ten wywołuje wiele naukowych dyskusji, ale też nie został jak dotąd zastąpiony innym obowiązującym w tak szerokim zakresie. Wątpliwości wzbudza fakt, że słowo „paradygmat” stosuje się zarówno w rozumieniu prawa naukowego, obowiązującej teorii naukowej, jak i jako zbiór filozoficznych przekonań stojących za danym podejściem naukowym. Samo pojęcie w kontekście teorii nauki (a nie w ujęciu językoznawczym) jako pierwszy wprowadził i upowszechnił Thomas Kuhn w wydanej w 1962 r. książce Struktura rewolucji naukowych ${ }^{21}$. Opisał w niej naukowy postęp jako proces nie tyle liniowy i kumulacyjny, co przede wszystkim zależny od rewolucji naukowych, mających miejsce wtedy, gdy obowiązujący paradygmat naukowy (prawo naukowe) zostaje zastąpiony nowym. Zanim to nastąpi, mamy do czynienia $\mathrm{z}$ „anomaliami” wewnątrz obowiązującego paradygmatu, $\mathrm{z}$ „kryzysem” związanym z pojawieniem się nowego sposobu postrzegania danej rzeczywistości całkowicie lub w jakiejś części, niemieszczącym się w dotychczas przyjętych regułach. W efekcie dochodzi do „wojny paradygmatów”. Typowym przykładem rewolucji naukowej jest według T. Kuhna przewrót kopernikański, a nowym paradygmatem, który w wyniku tej rewolucji zaistniał i zastąpił poprzedni - system kopernikański. Paradygmat według tego badacza wiąże się też z pojęciem „nauki normalnej” (a więc z okresem nierewolucyjnym, czasem stabilizacji w nauce, kiedy to dana grupa naukowa podziela te same poglądy) $i$ „ma on wskazywać na to, że pewne akceptowane wzory faktycznej praktyki naukowej - wzory obejmujące równocześnie prawa, teorie, zastosowania i wyposażenie techniczne - tworzą model, z którego wyłania się jakaś szczególna, zwarta tradycja badań naukowych"22.

Brytyjski socjolog Antoni Giddens zauważył, że kuhnowskie pojęcie paradygmatu podchwyciło wielu autorów, ale niewielu stosuje je poprawnie, większość z nich rozumie je jako synonim „teorii” ${ }^{23}$ (m.in. Karl Popper uznał, że koncepcja T.S. Kuhna nie ulega zniekształceniu, jeżeli przyjmiemy, że paradygmat to po prostu dominująca w nauce teoria ${ }^{24}$ ). Istotniejsze jednak jest to, że Struktura rewolucji

${ }^{20}$ B. Sławecki, Paradygmaty w naukach społecznych, [w:] Badania jakościowe. Podejścia i teorie, red. D. Jemielniak, Warszawa 2012, s. 58.

${ }_{21}$ T.S. Kuhn, Struktura rewolucji naukowych, tłum. H. Ostromęcka, Warszawa 2009.

22 Ibidem, s. 32.

23 A. Giddens, Nowe zasady metody socjologicznej, tłum. G. Woroniecka, Kraków 2009, s. 109.

${ }^{24}$ K. Popper, Normal Science and its Dangers, [in:] Criticism and Growth of Knowledge, eds I. Lakatos, A. Musgrave, Cambridge 1970, s. 53. 
naukowych zawiera poglądy wywiedzione $\mathrm{z}$ nauk ścisłych. To rodzi komplikacje przy stosowaniu wytycznych T.S. Kuhna wobec innych niż przyrodnicze dyscyplin naukowych, mimo że przekonanie o tym, iż zasady związane z pojmowaniem nauk przyrodniczych można stosować na innych polach, istnieje oraz istniało na długo przed powstaniem Struktur rewolucji naukowych. Przykładem są poglądy Antoine’a Nicolasa Condorceta, osiemnastowiecznego francuskiego filozofa-racjonalisty, który w rozprawie Szkic obrazu postępu ducha ludzkiego poprzez dzieje pytał:

Podstawą naszej wiary w nauki przyrodnicze jest przekonanie, że powszechne prawa, znane czy nieznane, które rządzą zjawiskami wszechświata, są konieczne i stałe; dlaczego zasada ta miałaby się okazać mniej słuszna w zastosowaniu do rozwoju intelektualnych i moralnych zdolności człowieka niż do innych procesów przyrody?25.

A jednak „paradygmatyczności” w dosłownym rozumieniu zawartym w Strukturze rewolucji naukowych nie można stosować wprost do nauk społecznych. Pisał o tym m.in. polski filozof i socjolog Józef Niżnik. Stwierdził on, że stosowanie w naukach społecznych idei T.S. Kuhna w jej pierwotnej postaci jest nie tylko nieporozumieniem, ale wręcz błędem. Zaznaczył przy tym:

Nieuchronna różnorodność paradygmatów w dyscyplinach społecznych jest rezultatem tych samych czynników, które zdaniem Kuhna decydują o wyborze jednego paradygmatu w naukach przyrodniczych (ponieważ są efektem twierdzenia: skoro, na przykład, żaden paradygmat nigdy nie rozwiązuje wszystkich problemów, w sporze między nimi rodzi się zawsze pytanie - rozwiązanie których problemów jest ważniejsze?) [...] Zagadnienie paradygmatu w naukach społecznych zyskuje cechy szczególne w porównaniu z tym zagadnieniem w naukach przyrodniczych. Przede wszystkim, w miejsce powszechnej zgody uczonych na jeden paradygmat mamy do czynienia z uprawnioną zgodą uczonych różnych społeczeństw na odmienne paradygmaty ${ }^{26}$.

Na różnice między naukami empirycznymi (przyrodniczymi) a humanistycznymi zwrócił uwagę Michał Heller, podkreślając, że te drugie z metodologicznego punktu widzenia są znacznie trudniejsze od empirycznych - wyróżniają się większą wieloznacznością reguł i interpretacji, rzadkim wykorzystywaniem modeli formalnych, a także posługują się hermeneutyką - sztuką odczytywania symboli.

25 A.N. Condorcet, Szkic obrazu postępu ducha ludzkiego poprzez dzieje, tłum. E. Hartleb, Warszawa 1957, s. 211.

26 J. Niżnik, Idea paradygmatu w naukach społecznych, „Człowiek i Światopogląd” 1979, nr 1, s. 145-146. 
Humaniści rozumują, empiryści wyjaśniają. Nauki humanistyczne badają wytwory kultury w kontekście człowieka i społeczeństwa, a nauki empiryczne wytwory natury. Przedmioty badań humanistów są jednostkowe, a empirystów - powtarzalne; wyniki badań tych pierwszych zawierają pierwiastki aksjologiczne, tych drugich są wolne i niezależne od ludzkich osądów ${ }^{27}$. Jak $\mathrm{w}$ to ujęcie wpisać nauki społeczne? B. Sławecki pisał, że „to jeden z podstawowych sporów w obrębie nauk społecznych, który toczy się od przeszło stu lat" ${ }^{28}$. Wyjaśnił, że problem podzielił uczonych na dwa "obozy” - zwolenników stosowania w naukach społecznych metod badań właściwych dla nauk przyrodniczych, „orędowników podejścia pozytywistycznego” oraz tych, którzy kwestionują takie rozwiązanie - „zwolenników podejścia rozumiejącego, zwanego także interpretującym czy też humanistycznym"29.

Pozytywizm, do dziś uważany za jeden z głównych paradygmatów w naukach społecznych, został zainicjowany przez twórcę terminu „socjologia” - filozofa Auguste’a Comte’a w drugiej połowie XIX wieku. Dotyczy poznania (epistemologii): „naukę pojmuje jako dziedzinę badania faktów ścisłych, w której stosuje się metody nauk przyrodniczych [...] Pozytywiści przyjmując twierdzenie Kanta o niepoznawalności rzeczy samej w sobie, koncentrują się na zjawiskach, "przejawach«, czyli na tym, co jest obserwowalne, doświadczalnie/empirycznie weryfikowalne" ${ }^{\prime 30}$. Skrajną formą tego poglądu jest scjentyzm, według którego „wiarygodną wiedzę o świecie można otrzymać tylko na drodze stosowania metod i osiągnięć nauk ścisłych, głównie przyrodniczych. Kategorie tych nauk są jedyne uprawomocnione do jakiegokolwiek filozofowania czy tworzenia teorii w naukach humanistycznych”31. „Podejście pozytywistyczne dominowało w naukach społecznych przez ponad pół wieku”32 - pisał B. Sławecki. A dalej stwierdził: „W latach sześćdziesiątych ubiegłego stulecia nastąpił rozkwit analiz prowadzonych w duchu socjologii rozumiejącej (interpretatywnej), które wywarły ogromny wpływ na kształt współczesnych nauk społecznych"33.

Zjawisko, o którym pisał badacz (tzw. socjologia rozumiejąca), jest konsekwencją tzw. przełomu antypozytywistycznego. Przełom ten, określany jako intelektualny ruch sprzeciwu wobec filozofii scjentystycznej i metodologii naturalistycznej, nastąpił pod koniec XIX wieku. Decydującą rolę w krytyce pozytywistycznego modelu nauk przyrodniczych w kwestii pojmowania rzeczywistości historycznej,

27 M. Heller, Filozofia nauki, Kraków 2016, s. 39-41.

${ }_{28}$ B. Sławecki, Znaczenie paradygmatów w badaniach jakościowych, [w:] Badania jakościowe. Podejścia i teorie, red. D. Jemielniak, Warszawa 2012, s. 61.

29 Ibidem, s. 61-62.

30 A.J. Karpiński, Słownik pojęć filozoficzno-socjologicznych, Gdańsk 2006, s. 180.

${ }^{31}$ Ibidem, s. 209-210.

32 B. Sławecki, Znaczenie paradygmatów..., s. 65.

${ }^{33}$ Ibidem. 
społecznej i kulturowej odegrał neoidealista Wilhelm Dilthey (1837-1911). „Był twórcą pojęcia »nauk o duchu «, które później nazwano »naukami humanistycznymi«, usiłował odgraniczyć ich pole działania od nauk przyrodniczych [...]. Waga jego dzieł polega na przecieraniu drogi, którą podążył późniejszy rozwój socjologii i psychologii społecznej” ${ }^{34}$. Do „kryzysu nauki” i zaistnienia zjawiska przełomu antypozytywistycznego przyczyniła się też filozofia Henriego Bergsona, twórcy intuicjonizmu (1859-1941). „Sławę uzyskała jego teoria »ja głębokiego «, ukrytego pod powierzchnią osobowości "społecznej«" 35 . Ciekawie o przełomie antypozytywistycznym i czasie, który go poprzedzał, pisała Barbara Skarga w książce Kłopoty intelektu. Między Comte'em a Bergsonem:

Arsenał pojęć, którym operowali wielcy systematycy początku XIX wieku, stopniowo się zmieniał. [...] Nadal mówiono o fakcie, prawie naukowym, organizmie, postępie, produkcji, ale mniej już dyskutowano na temat historii, więcej o ewolucji. Nie roztrząsano kwestii związanych z rozumem, badano bowiem świadomość lub inteligencję, nie rozprawiano o ludzkości, tej Najwyższej Istocie Comte’a, lecz po prostu o społeczeństwie. [...] Nauka o człowieku nabierała jakby nowych odcieni. Nie dawała się tak łatwo modelować na wzór nauk przyrodniczych, coraz silniej orientowała się ze względu na świat wartości, zrywała ze starym a tak złudnym postulatem obiektywności, ukazując, że zawsze z tego, co dane, coś się wybiera i konstruuje. I prawa, które ustalała, traciły ten swój rygorystyczny charakter, stawały się, jak mówił Bergson - giętkie, elastyczne, zaczynały bowiem być traktowane nie jako opis obiektywnych i niezmiennych prawidłowości zachodzących między zjawiskami, lecz jako instrument, który pozwala niektóre z typów zjawisk ludzkich, tak nieuchwytnych, wyjaśniać, klasyfikować, porządkować36.

Powyższe wyjaśnienia i definicje filozoficznych zjawisk, zasygnalizowane być może zbyt wybiórczo i w zbyt wielkim skrócie, są w artykule konieczne, albowiem odbicie wspomnianych idei - zwłaszcza tych stojących do dziś w opozycji (pozytywizm kontra humanizm wynikający z przełomu antypozytywistycznego), a także wielu innych idei tu nie wzmiankowanych, znajdujemy w obecnie obowiązujących klasyfikacjach paradygmatów nauk społecznych, z perspektywy których odbywają się społeczne badania, w tym nasze rodzime badania czytelnictwa. W kwestii pojęcia „paradygmatu” podążam w tym artykule za stwierdzeniem, iż jest to zbiór idei stojących za danym podejściem naukowym.

${ }_{34}$ J. Didier, Stownik filozofii, tłum. K. Jarosz, Katowice 1995, s. 81.

${ }^{35}$ Ibidem, s. 36.

36 B. Skarga, Kłopoty intelektu. Między Comteem a Bergsonem, Warszawa 2017. 


\section{Rodzime badania czytelnictwa a paradygmaty}

Jak wspomniano na wstępie, pod rozwagę wzięto dwa aktualne badania czytelnictwa w Polsce. Pierwsze, wiodące i najważniejsze tego typu, podsumowane raportem Stan czytelnictwa w Polsce w 2016 roku, zrealizowała Pracownia Badań Czytelnictwa Biblioteki Narodowej na ogólnopolskiej, reprezentatywnej próbie 3149 respondentów, w wieku co najmniej 15 lat, dobranej według random route. „Wywiady przeprowadzono metodą CAPI (Computer Assisted Personal Interview) - wspomaganego komputerowo wywiadu kwestionariuszowego" - czytamy we wstępie raportu z badań opublikowanego w $2016 \mathrm{roku}^{37}$. Kwestionariusz wywiadu składał się przede wszystkim z pytań, które wystąpiły w poprzednich edycjach badania, przy czym zachowano ich kolejność, tak aby wyniki były porównywalne z rezultatami uzyskanymi w ubiegłych latach.

Drugie wzięte tu pod uwagę badanie związane z czytelnictwem w Polsce przeprowadzono na zlecenie Fundacji Centrum Cyfrowe w ramach projektu badawczego „Zmiany w kulturze czytelniczej w Polsce w kontekście upowszechnienia e-tekstów i urządzeń pozwalających z nich korzystać”. Współfinansowane przez program Obserwatorium Kultury 2015 Ministerstwa Kultury i Dziedzictwa Narodowego odbyło się pod hasłem „Jak czytają Polacy?”. Jego autorami są Małgorzata Kisilowska, Magdalena Paul i Michał Zając - pracownicy naukowi UW. Projekt, jak informują naukowcy w raporcie, „zrealizowano z wykorzystaniem metod i narzędzi badawczych nauk społecznych i humanistycznych, i obejmował on następujące komponenty: 1) desk research, na który złożyły się: analiza literatury, przegląd raportów badawczych i analiza dyskursu medialnego; 2) dwa zogniskowane wywiady grupowe z bibliotekarzami z placówek publicznych, dotyczące popularności oraz postaw wobec nowych form książki, jakie wyrażają zarówno użytkownicy, jak i sami bibliotekarze oraz 3) dwadzieścia pogłębionych wywiadów indywidualnych z dorosłymi respondentami nt. ich preferencji i zwyczajów czytelniczych, uzupełnionych badaniami dzienniczkowymi”"38. Raport z tych badań, podobnie jak raport z badań BN, opublikowano w 2016 roku.

W badaniu Biblioteki Narodowej przy doborze próby stosowano technikę random route. Polega ona na wylosowaniu punktów startowych (adresowych) i przeprowadzaniu ankiet $\mathrm{z}$ osobami, które zastano $\mathrm{w}$ domu i spełniły określone wymagania odnośnie do charakterystyk zmiennych (np. płci, wieku). Głównym wnioskiem z tych badań jest informacja, że jakąkolwiek książkę w 2016 roku przeczytało 37\% Polaków w wieku co najmniej piętnastu lat, a 10\% czytało siedem lub więcej pozy-

37 Stan czytelnictwa $w$ Polsce $w 2016$ roku, op. cit., [dostęp: 15.05.2018].

${ }_{38}$ M. Kisilowska, M. Paul, M. Zając, op. cit., s. 7. 
cji. Dane można porównać $\mathrm{z}$ wynikami badań realizowanych $\mathrm{w}$ ubiegłych latach i wyciągnąć wnioski na temat tego, czy czytelnictwo w Polsce spada, rośnie, czy też utrzymuje się na tym samym poziomie (od dużego tąpnięcia w latach 2006-2008 trzyma podobny poziom).

W badaniu realizowanym przez Fundację Centrum Cyfrowe analizowano przede wszystkim:

- wpływ upowszechnienia e-tekstów i czytników na zmiany w zachowaniach czytelniczych Polaków w latach 2010-2015, w tym potencjalne zmiany w czytelnictwie ludycznym, definiowanym jako kontakt $\mathrm{z}$ literaturą, realizowany $\mathrm{w}$ celach rozrywkowych, a nie utylitarnych dotyczących sfery edukacji lub pracy zawodowej;

- wpływ zaawansowania kompetencji medialnych na intensywność korzystania z e-tekstów;

- oraz wpływ dostępności e-tekstów na zachowania społeczne związane z tworzeniem się kręgów czytelniczych.

We wnioskach z badań próbowano także zdefiniować pojęcie „e-czytania”, przy czym, co ważne, na podstawie definicji i opisów osób badanych, które poproszono o wyjaśnienie osobistego rozumienia tego pojęcia ${ }^{39}$.

Omówione powyżej dwa badania, choć dotyczą czytelnictwa, ujmują je z zupełnie innych perspektyw badawczych, stosują różne metody badawcze - stoją za nimi odmienne paradygmaty nauk społecznych. Bez wątpienia wybór paradygmatu naukowego ma zasadniczy wpływ na dobór metod badawczych. Autorzy powyższych naukowych obserwacji nie zdradzają jednak w raportach swojego stanowiska w tym zakresie (tj. zakresie paradygmatów). Mimo to spróbuję umiejscowić ich badania właśnie $\mathrm{w}$ tym kontekście.

W związku z wywiedzionym wcześniej wnioskiem, że czytanie jest praktyką społeczną, badania związane z czytelnictwem są rozważane tu wyłącznie w wybranych paradygmatach nauk społecznych. Jedną z najczęściej przytaczanych klasyfikacji paradygmatów nauk społecznych opracowali już niemal 40 lat temu Gibson Burrell i Gareth Morgan ${ }^{40}$. Biorąc pod uwagę założenia leżące u podstaw różnych teorii społecznych (o tym, jak wiele ich było i jest, świadczy chociażby publikacja Jerzego Szackiego Historia myśli socjologicznej ${ }^{41}$ ), stworzyli oni kompozycję czterech dwubiegunowych, kluczowych obecnie dla nauk społecznych, paradygmatów. Pisał o tym m.in. B. Sławecki: „Pierwszy wymiar - subiektywizm-obiektywizm - odnosi się do dyskusji poświęconej naturze nauk społecznych. Drugi: regulacja-radykalna

39 Ibidem, s. 12-13, 179-180.

40 G. Burrel, G. Morgan, Sociological Paradigms and Organizational Analysis, London 1979, s. 22.

41 J. Szacki, Historia myśli socjologicznej, Warszawa 2002. 
zmiana, dotyczy sporu na temat natury społeczeństwa"42. B. Sławecki wyjaśnił, że pierwszy wymiar opracowano w wyniku dyskusji w obszarze założeń ontologicznych, epistemologicznych i metodologicznych, a drugi mówi o tym, że człowiek albo dąży do oswobodzenia się ze struktur ograniczających jego potencjał rozwojowy (radykalna zmiana), albo trwa w społeczeństwie ujmowanym w kategorii jedności i utrzymującym się jako jeden byt (regulacja). W obrębie tych dwóch wymiarów Burrell i Morgan umieścili cztery, uznawane za podstawowe, paradygmaty w naukach społecznych: funkcjonalizm (koncepcja nauki wzorowana na koncepcji nauki nauk przyrodniczych; koncepcja społeczeństwa jako organizmu, z której wynika, że żadnego elementu kultury nie można zrozumieć w izolacji od całości, jaką jest każda kultura ${ }^{43}$ ), interpretatywizm (wspomniane wyżej podejście rozumiejące, humanistyczne; subiektywistyczna wizja natury społecznej i teorii poznania, rzeczywistość powinna być rozumiana w takiej postaci, w jakiej jawi się jej uczestnikom, podstawowe pytanie: jak konstruowany jest świat w codziennych działaniach aktorów społecznych ${ }^{44}$ ), radykalny humanizm (pojmowany m.in. jako twórczy sprzeciw wobec myślenia pozytywistycznego, np. w poglądach Ericha Fromma ${ }^{45}$, także: świat nie jest materialny, jest „produktem ludzkich umysłów”, społeczeństwo widziane jest jako nastawione przeciw człowiekowi, ludzie są w nim „wtłaczani” w różnego rodzaju ograniczenia ${ }^{46}$ ) i radykalny strukturalizm (zjawiska, które występują w ludzkim życiu, można zrozumieć wyłącznie za pośrednictwem ich wzajemnych związków, te związki tworzą pewną strukturę ${ }^{47}$; za czołowego strukturalistę uważa się Claude’a Lévi-Straussa ${ }^{48}$ ).

Jeśli wybór paradygmatu badawczego ma zasadniczy wpływ na dobór metod badawczych, to w sytuacji braku takiego oficjalnego (świadomego) wyboru można domniemywać, które paradygmaty badawcze stoją za wyborem metod badawczych. Badania Biblioteki Narodowej dotyczące poziomu czytelnictwa w Polsce są typowymi badaniami ilościowymi. Zorganizowane już po raz czternasty, a po raz czwarty na dużej, ponadtrzytysięcznej grupie osób, odpowiadają na pytania: ile, gdzie, kto i co czyta. Pomiaru dokonywano na podstawie zmiennych, które można zmierzyć, policzyć, podsumować. W badaniach tego typu istotą jest właśnie pomiar, aby móc porównać ze sobą (z użyciem wiedzy statystycznej) zebrane wyniki. Cała statystyka

42 B. Sławecki, op. cit., s. 75.

43 A.J. Karpiński, Słownik pojęć filozoficzno-socjologicznych, Gdańsk 2006, s. 111-112.

44 B. Sławecki, op. cit., s. 78

${ }_{45}$ T. Bilicki, Krytyka autorytetu w pedagogice radykalnego humanizmu Ericha Fromma, „Studia z Teorii Wychowania” 2011, nr 2/1, vol. 2, s. 73-79.

46 B. Sławecki, op. cit., s. 79.

47 S. Blackburn, Oxfordzki słownik filozoficzny, Warszawa 1997, s. 379.

48 E. Lach, Lévi-Strauss, tłum. P. Niklewicz, Warszawa 1998. 
dotyczy badań typu ilościowego. Badania takie swój rodowód mają w naukach przyrodniczych i w socjologii, charakterystyczne są dla podejścia pozytywistycznego i neopozytywistycznego ${ }^{49}$. Ponadto badania ilościowe charakteryzuje dedukcyjny sposób badania, czyli poszukuje się danych potwierdzających teorię. Jak pisał B. Sławecki, podstawowe różnice między podejściem pozytywistycznym a rozumiejącym/ humanistycznym przejawiają się w odpowiedziach na trzy pytania: Jaka jest relacja między osobą prowadzącą badania naukowe a przedmiotem badania naukowego?; Jaka jest relacja pomiędzy poznawaną rzeczywistością a przekonaniami tej osoby?; Jaki jest cel badań społecznych?. Badacze pozytywistyczni na pierwsze pytanie odpowiedzą, że fakty społeczne można analizować z pozycji zewnętrznego obserwatora $\mathrm{i}$ istnieją one wobec obserwatorów niezależnie. Przy pytaniu drugim stwierdzą, że rzeczywistość i badania społeczne są neutralne w stosunku do przekonań osób prowadzących badania, więc badania są obiektywne, a na pytanie trzecie dadzą odpowiedź, że celem badań jest wykrycie trwałych związków pomiędzy faktami. Takim trwałym związkiem w badaniach czytelnictwa BN jest na przykład wykazanie z perspektywy kilku lat, że dzieci z rodzin nieczytających książek w ponad 80\% przypadków też nie będą czytelnikami książek; nieczytający to także „często osoby starsze - powyżej 50. roku życia, relatywnie gorzej sytuowane, z wykształceniem podstawowym i zasadniczym zawodowym oraz przewagą robotników i rolników" oraz że badanie jest zorientowane na przewidywanie, kontrolowanie i naprawianie świata społecznego ${ }^{51}$ (np. próby zwiększania czytelnictwa wśród dzieci osób nieczytających przez m.in. dofinansowywanie z budżetu państwa akcji typu „Pierwsza książka mojego dziecka”"52).

Zupełnie inaczej na postawione powyżej trzy pytania odpowiedzą badacze reprezentujący podejście rozumiejące/humanistyczne. O relacji między osobą prowadzącą badania a przedmiotem badania powiedzą, że jest wzajemna, o relacji przekonań osób prowadzących badania z rzeczywistością społeczną będą twierdzić, że niemożliwe jest oderwanie rzeczywistości od osoby, która ją tworzy, a więc badania muszą być subiektywne, w przypadku celów badań społecznych opowiadają się

49 Pozytywistyczne i neopozytywistyczne podejście naukowe to wyjaśnienia nomotetyczne (związane z danymi ilościowymi), które skupiają się na całościowym ujęciu klasy zjawisk i określaniu głównych czynników wyjaśniających. Opozycyjne, związane z metodami jakościowymi wyjaśnienie idiograficzne pozwala na pogłębienie, rozszerzenie zrozumienia tematu przez badacza - na pogłębioną analizę konkretnego przypadku, jednak bez możliwości estymowania na populację. E. Babbie, Podstawy badań społecznych, tłum. W. Betkiewicz, Warszawa 2008, s. 46-67.

50 Stan czytelnictwa $w$ Polsce w 2016 roku, op. cit., [dostęp: 15.05.2018], s. 19.

51 B. Sławecki, op. cit., s. 63-64.

${ }^{52}$ Zob. „Pierwsza książka mojego dziecka”, Ministerstwo Kultury i Dziedzictwa Narodowego, [online]. Dostępny w World Wide Web: http://www.mkidn.gov.pl/pages/posts/bdquopierwsza-ksiazka-mojego-dzieckardquo-3651.php [dostęp: 17.05.2018]. 
zaś za „zrozumieniem działań ludzkich w ich naturalnym kontekście”, znalezieniu nowych znaczeń i odpowiedzi na pytanie ,jak”.

Podejście takie reprezentują naukowcy wybierający jakościowe metody badawcze. Przypadek przytaczanych badań czytelnictwa zrealizowanych przez Centrum Cyfrowe jest ich typowym przykładem. W polu poszukiwania nowych znaczeń znalazła się tu bowiem na przykład definicja pojęcia „e-czytelnictwa”, a pytanie „jak” postawione już w tytule i wnioskach z tych badań wskazuje bezpośrednio na ich jakościowy i realizowany z perspektywy rozumiejącej charakter (Jak czytają Polacy?). „Ile czytają Polacy?” i „Jak czytają Polacy?” - tak odmiennie zadane pytania i szukanie odpowiedzi na nie plasuje oba badania dwubiegunowo, kolejno - Biblioteki Narodowej (ile?) w perspektywie pozytywistycznej, a Centrum Cyfrowego (jak?) w perspektywie humanistycznej. Przypatrując się tym badaniom pod kątem ontologicznym w kwestii przedmiotu ich analiz, czyli czytelnictwa, można próbować pokusić się również o wywiedzenie podejścia filozoficznego badaczy. Według Romana Ingardena, podstawowym sporem ontologicznym jest spór między realizmem a idealizmem ${ }^{53}$.

Realizm jako doktryna filozoficzna głosi, że nasze poznanie sięga prawdziwej rzeczywistości. [...] przeciwstawia się idealizmowi, według którego poznajemy tylko zjawiska (fenomeny), a nie rzeczywistość samą w sobie. [...] Platon daje jego najsłynniejszy przykład: doświadczenie „reminiscencji”, wg którego metodą zwykłej refleksji odkrywamy powtórnie elementarne prawdy matematyczne i ideały moralne, wystarczyłoby, aby udowodnić ich realność w sobie i pierwotne myślenie w umyśle ludzkim. Ten punkt widzenia przejęty został w naszych czasach przez fenomenologię Husserla i logiczny pozytywizm Wittgensteina ${ }^{54}$.

Idealizm to z kolei doktryna „negująca istnienie świata zewnętrznego i redukująca go do przedstawień, jakie o nim posiadamy (znamy tylko nasze wyobrażenia)" 55 . Praktyka czytania - czy istnieje poza badaczami jej „rozmiarów” w Polsce? Mniemam, iż reprezentujący podejście ilościowe naukowcy Biblioteki Narodowej zakładają, że tak. Z kolei badacze działający w imieniu Centrum Cyfrowego analizują zjawisko jakościowo oraz metodą indukcji, w dodatku w ramach teorii ugruntowanej (rzeczywistość społeczną najlepiej rozumieją zaangażowani w nią aktorzy $\left.{ }^{56}\right)$, przez próbę ostrożnego definiowania nowych pojęć w zakresie czytel-

53 A. Nowak, Słownik pojęć filozoficznych Romana Ingardena, red. L. Sosnowski, Kraków 2001, s. 177.

${ }^{54}$ J. Didier, op. cit., s. 324.

${ }^{55}$ Ibidem, s. 161.

${ }^{56}$ E. Babbie, Paradygmaty, teoria i badania społeczne, [w:] idem, Podstawy badań społecznych, tłum. W. Betkiewicz, Warszawa 2008, s. 70, 332. 
nictwa przy pomocy wyobrażeń respondentów bliżsi są idealistom niż realistom. Pod kątem epistemologicznym zaś empirystom, a nie racjonalistom (w badaniach tych przywiązywano wagę np. do doznań zmysłowych związanych z przedmiotem książki jako nośnikiem treści; w poszukiwaniu odpowiedzi na pytanie: „Jak czytają Polacy?", doznania zmysłowe miały o tyle duże znaczenie, że decydowały wśród respondentów o wyborze „nośnika”, a tym samym sposobu i okoliczności czytania ${ }^{57}$ ).

Podążając dalej metodą wykazywania dwubiegunowości opisywanych badań nad czytelnictwem, można także zaznaczyć, że badania Biblioteki Narodowej podobnie do nauk nomotetycznych próbują uchwycić to, co wspólne, powtarzalne i istotne dla wszystkich analizowanych przypadków (np. Ile książek przeczytałeś w ciągu 12 miesięcy poprzedzających badanie?; Ile woluminów zawiera twój księgozbiór domowy ${ }^{258}$ ) i przestrzegają ustalonych procedur i technik badawczych, zaś badania Centrum Cyfrowego mają charakter analizy idiograficznej „bazującej na przekonaniu, że zrozumienie świata społecznego jest możliwe jedynie poprzez dotarcie do informacji z pierwszej ręki, posiadanych przez uczestników zdarzeńn 59 . Pierwsze badania cechuje determinizm (związek przyczynowo-skutkowy pojawia się w wielu wnioskach, np. w domach o bardzo małych księgozbiorach lub bez książek domownicy nie korzystają także z bibliotek ${ }^{60}$ ), drugie - relatywizm.

Wracając do czterech przedstawionych wyżej paradygmatów w naukach społecznych opisanych przez Burrella i Morgana - funkcjonalizm, radykalny strukturalizm, radykalny humanizm, interpretatywizm - ilościowe badania Biblioteki Narodowej dotyczące czytelnictwa umieściłabym w paradygmacie funkcjonalnym, a jakościowe podejście Fundacji Centrum Cyfrowego - w interpretatywizmie. Przyjmując dedukcyjne rozumowanie, badacze Biblioteki Narodowej w 2016 ustalili z góry pewien słownik pojęć, którym posługują się rokrocznie: „Tak jak przed rokiem stosowane terminy podzieliliśmy na trzy grupy. Te oznaczone literą "K " mówią najwięcej o naszej konceptualizacji problemów badawczych; oznaczone »O « to najważniejsze definicje operacyjne, którymi posługujemy się w pracy; »W « oznacza natomiast główne wskaźniki”. Wśród nich są np.: „K” - kultura książki i uczestnictwo w kulturze książki, socjalizacja czytelnicza, „O” - czytelnik książek, omniczytelnik, generalnie nieczytający, „W” - indeks socjalizacji czytelniczej. Badacze wprowadzają segmentację czytelników, dzieląc ich na grupy i podgrupy jako narzędzie analityczne, stosując segmentację klas ukrytych (wyjaśnienie metody - patrz raport s. 17), budują modele strukturalne, próbując ocenić czynniki sprzyjające i niesprzyjające czytaniu

\footnotetext{
57 M. Kisilowska, M. Paul, M. Zając, op. cit., s. 180.

58 Stan czytelnictwa w Polsce w 2016 roku, op. cit., [dostęp: 17.05.2018], s. 12-13.

59 B. Sławecki, op. cit., s. 71.

${ }^{60}$ Stan czytelnictwa $w$ Polsce w 2016, op. cit., [dostęp: 17.05.2018], s. 19.
} 
książek (wśród nich jest np. poziom wykształcenia respondenta, ale ważną „funkcję" pełnią też rodzice respondenta oraz ich poziom wykształcenia - patrz raport s. 23), czy wreszcie dzielą całe społeczeństwo na grupy zawodowe, badając czytelnictwo wśród tych grup i wywodząc, że tendencja zmierzająca ku mniejszemu zaangażowaniu w czytanie książek jest wyraźna nie tylko w skali całego społeczeństwa, lecz także wśród „elit zawodowo-intelektualnych”, ponieważ procent „przedstawicieli kadr kierowniczych i specjalistów” wyraźnie zmniejsza się od 2012 roku, stawiając tę grupę obecnie bardziej wśród „czytelników tradycyjnych” niż „intensywnych”1.

Za takim podejściem do badań stoi wspomniany wyżej paradygmat funkcjonalny.

Funkcjonalizm, znany niekiedy także jako „teoria systemów społecznych”, wyrasta z pojęcia wprowadzonego m.in. przez Comte’a - „byt społeczny, taki jak organizacja albo całe społeczeństwo, może być postrzegany jako organizm. [...] Patrząc na społeczeństwo jako na system społeczny, szuka się «funkcji», jakie pełnią jego różne składniki" ${ }^{2}$.

Pojęcia takie jak funkcja, system czy społeczna struktura wprowadził do socjologii angielski filozof Herbert Spencer (1820-1903), jednak dwudziestowieczne rozumienie funkcjonalizmu jest ujmowane przez pryzmat poglądów francuskiego filozofa Émile’a Durkheima (1858-1917) i kolejnych rozwijających ten pogląd filozofów i socjologów, co zaznaczył w swym artykule Paradygmat funkcjonalny Herberta Spencera ${ }^{63}$ Kamil Kaczmarek. W podrozdziale „Późniejszy funkcjonalizm” wyjaśnił on:

Rolę pośrednika między Durkheimem a nowoczesnym funkcjonalizmem odegrał przede wszystkim Radcliffe-Brown. Wprawdzie punktem wyjścia uczynił analogię organiczną, jednak nie zastosował jej jako narzędzia teoretycznego z dyscypliną właściwą w tym względzie Spencerowi. Dlatego strukturę organizmu mógł określić szerzej niż Spencer, jako „zespół zależności między odrębnymi jednostkami”. Terminem „funkcja” - za Durkheimem - określał konsekwencje działania, nie zaś działanie. [...] Funkcję może wg niego pełnić nie tylko konkretny organ społeczeństwa, ale dowolny zwyczaj społeczny czy też „dowolna powtarzająca się czynność”. Pojęcie potrzeb jest dla niego równoznaczne z „koniecznymi warunkami istnienia społeczeństw ludzkich”. Jak zauważają Jonathan H. Turner i Alexandra Maryanski, funkcjonalizm, po przejęciu go przez antropologów utracił wszelkie ambicje, by badać genezę zjawisk, a tym samym zerwał ostatnie więzi z ewolucjonizmem, jakie pozostawały jeszcze w koncepcji Durkheima ${ }^{64}$.

61 Ibidem, s. 25-26.

62 E. Babbie, Paradygmaty, teoria i badania..., op. cit.

63 K. Kaczmarek, Paradygmat funkcjonalny Herberta Spencera, „Studia Socjologiczne” 2013, nr 2 (209), s. 32-46.

64 Ibidem, s. 42 
Co bardzo istotne - funkcjonalizm usuwa z pola widzenia jednostkę jako indywidualność.

Tymczasem w jakościowym badaniu Fundacji Centrum Cyfrowego przez pogłębione wywiady indywidualne pytano o kontakt $\mathrm{z}$ technologiami cyfrowymi i ich wpływ na czytanie w dość szczegółowym i zawężonym zakresie - w kontekście spędzania wolnego czasu bądź czytania „dla przyjemności”. Przynależność respondentów do struktur społecznych nie miała tu zbyt dużego znaczenia. „Respondenci zostali dobrani w taki sposób, aby grupa do pewnego stopnia odzwierciedlała populację Polaków, którzy intensywnie biorą udział w praktykach czytelniczych”65. A więc deklaracja częstego i intensywnego czytania była warunkiem uczestniczenia w badaniu. „Konstrukcja grupy podyktowana była założeniami projektu badawczego - głównym celem nie było osiągnięcie wyników reprezentatywnych w skali ogólnopolskiej, ale zidentyfikowanie i opisanie zjawisk związanych z e-czytelnictwem o charakterze jakościowym" - wyjaśnili autorzy badania. Respondenci przez kilka dni, bez obecności badaczy, prowadzili „dzienniczki”, rejestrując praktyki czytelnicze ${ }^{66}$.

$\mathrm{Na}$ tej podstawie badacze określili, jak zmienia się czytanie na różnych nośnikach w ciągu dnia. „Zaczynamy od czytania na smartfonach artykułów, do których docieramy »odbijając się« od linków w serwisach społecznościowych, w połowie dnia czytamy gazety w druku i na ekranie komputera stacjonarnego, a wieczorem sięgamy po książkę drukowaną ${ }^{67}$. Wnioski te nie są jednak efektem eksperymentu. Badacze nie budowali hipotezy, efekty ich obserwacji są wynikiem rozumowania indukcyjnego. Autorzy projektu naukowego Jak czytają Polacy są interpretatywistami. Jak pisał Piotr Chomczyński, próbując przybliżyć paradygmat interpretatywny w kontekście metodologicznym:

Punktem wspólnym założeń teoretycznych i metodologicznych, które określa się zbiorczym mianem paradygmatu interpretatywnego, jest zasadnicza zgoda obejmująca prawie całkowite odrzucenie i przeciwstawienie się założeniom pozytywizmu, na czele $\mathrm{z}$ wiążącymi się z nim teoriami funkcjonalizmu i normatywnymi. Interpretatywiści nie akceptują pozytywizmu logicznego, stawiającego za wzór założenia nauk fizycznych, spośród których wymienia się: postrzeganie i prowadzenie badań w kategoriach logiki eksperymentu, dążenie do budowania praw uniwersalnych, jak również stosowanie języka obserwacji neutralnej przyznającej prymat zjawiskom bezpośrednio obserwowalnym. [...] Paradygmat interpretatywny wyrasta z założeń metodologicznych

\footnotetext{
${ }^{65}$ M. Kisilowska, M. Paul, M. Zając, op. cit., s. 150.

${ }^{66}$ Ibidem, s. 151-153.

${ }^{67}$ Ibidem.
} 
przedstawicieli Szkoły Chicago oraz ich zwolenników (m.in. J. Dewey, Ch.H. Cooley, H. Mead, H. Blumer i in. $)^{68}$.

Poniższy schemat podsumowuje przywoływane w tekście badania dotyczące czytelnictwa z uwzględnieniem przytoczonych paradygmatów.

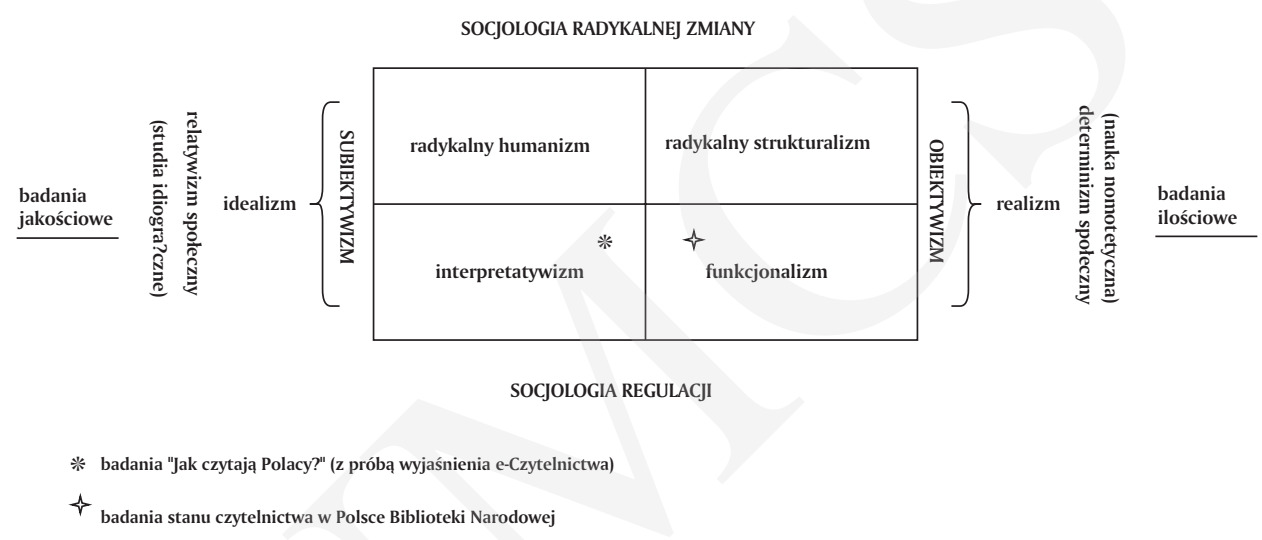

Ryc. 1. Badania dotyczące czytelnictwa

(w centralnej części schematu diagram B. Sławeckiego).

Schemat własny na podstawie: G. Burrel, G. Morgan, Sociological Paradigms and Organizational Analysis, Londyn 1979 oraz B. Sławecki, Znaczenie paradygmatów w badaniach jakościowych, [w:] Badania jakościowe. Podejścia i teorie, red. D. Jemielniak, Warszawa 2012.

\section{Podsumowanie}

Na siatkę stworzoną przez B. Sławeckiego (w centralnej części schematu) na podstawie opisów G. Burrela i G. Morgana ${ }^{69}$ nałożono dalsze zmienne oraz umiejscowiono na niej ilościowe i jakościowe badania przytaczane w artykule. Oczywiście temat stojących za badaniami paradygmatów jest tu zaledwie zasygnalizowany. Napisano na ten temat wiele artykułów, w tym wiele polemizujących. W ich obrębie mieszczą się rozmaite teorie, o samym na przykład paradygmacie interpretatywnym pisała Elżbieta Hałas:

[I]nterpretatio jest łacińskim odpowiednikiem greckiego hermeneia, oznaczającego zarówno rozumienie, wyłożenie, wyjaśnienie, objaśnienie, przekład jak i ocenę. Dla

${ }^{68}$ P. Chomczyński, Paradygmat interpretatywny, [w:] Słownik socjologii jakościowej, red. K.T. Konecki, P. Chomczyński, Warszawa 2012, s. 212-213.

${ }^{69}$ G. Burrel, G. Morgan, Sociological Paradigms and Organizational Analysis, London 1979. 
upowszechnienia pewnej odmiany interpretacjonizmu, szczególnie w naukach społecznych, przyczyniła się fenomenologia, a w socjologii fenomenologia społeczna Alfreda Schutza. Z dużym prawdopodobieństwem to recepcja dzieł Schutza w USA przyczyniła się do zastąpienia wcześniejszych określeń takich jak nawiązująca do tradycji hermeneutycznej socjologia rozumiejąca, a także socjologia humanistyczna przez przymiotnik „interpretacyjna" ${ }^{\text {" }}$.

A więc należałoby pewnie (w kwestii tego jednego tylko paradygmatu, w obrębie innych znalazłyby się inne nieporuszone zagadnienia) wyjaśnić tu jeszcze pojęcie "fenomenologii” i „hermeneutyki”. Na to jednak nie pozwala zakładana objętość niniejszego artykułu.

Zaznaczyć jednak trzeba, że analizowano tu dwa odrębne badania związane z czytelnictwem - dwie odrębne perspektywy badawcze, w obrębie jednej tylko klasyfikacji paradygmatów nauk społecznych autorstwa G. Burrella i G. Morgana, przy świadomości, że istnieją inne. Na przykład koncepcja pięciu podstawowych paradygmatów autorstwa Egona Guby i Yvonny Lincoln. Przyjmuje ona takie perspektywy badawcze jak pozytywizm, postpozytywizm, teorię krytyczną, konstruktywizm i dodany w 2000 r. paradygmat uczestniczący ${ }^{71}$ (ciekawe byłoby rozważenie badań jakościowych Centrum Cyfrowego w kontekście paradygmatu uczestniczącego). Można byłoby rozważyć też przywołane badania nad czytelnictwem w kontekście paradygmatów feministycznych - wszak badania Biblioteki Narodowej charakteryzują zmienne również pod kątem płci, a w jakościowych badaniach Centrum Cyfrowego 80\% respondentów w grupie osób poddanych wywiadom pogłębionym stanowiły kobiety lub np. w kontekście pragmatyzmu. Także ujęte pod kątem filozoficznym kryterium „prawdy” w tych badaniach mogłoby być tematem na oddzielny artykuł, podobnie jak próba odpowiedzi na pytanie, co wnoszą one w postęp i rozwój nauk, które prezentują.

Jak pisał cytowany wyżej J. Niżnik, w odpowiedzi na stwierdzenie Ralfa Dahrendorfa sformułowane w związku z opozycją w naukach społecznych teorii systemowej z teorią konfliktu:

„[D]la analizy socjologicznej społeczeństwo jest dwugłowym Janusem, i jego dwie twarze stanowią równoważne aspekty tej samej rzeczywistości”: Nie. Należy stwierdzić, że dla analizy socjologicznej społeczeństwo jest istotą wielogłową. W świetle dotychczasowych

${ }^{70}$ E. Hałas, Jakie nowe zasady metody socjologicznej? O wielości socjologii interpretacyjnych, [w:] W kręgu socjologii interpretatywnej - zastosowanie metod jakościowych, red. J. Leoński, A. KołodziejDurnaś, Szczecin 2005, s. 8.

${ }^{71}$ E.G. Guba, Y.S. Lincoln, Kontrowersje wokół paradygmatów, sprzeczności i wyłaniające się zbieżności, [w:] Metody badań jakościowych, red. N. Denzin, Y.S. Lincoln, tłum. K. Podemski, Warszawa 2009. 
rozważań rozmaitość teoretycznych stanowisk w naukach społecznych jawi się przede wszystkim jako ilustracja wieloaspektowości rzeczywistości społecznej ${ }^{72}$.

Znajomość paradygmatów i filozofii, z jakich się wywodzą, może pomóc obronić własne badania i wywody w sytuacji, o której pisali E. Guba i Y.S. Lincoln:

Trudno byłoby dziś przegapić wyraźny zwrot nauk społecznych w kierunku bardziej interpretacyjnych, postmodernistycznych i krytycznych praktyk oraz teoretyzowania. Ta niepozytywistyczna orientacja stworzyła kontekst (otoczenie), w którym właściwie każde badanie może zostać zakwestionowane przez zwolenników konkurencyjnych paradygmatów $w^{73}$.

Trudno odmówić też racji stwierdzeniom przytaczanego wielokrotnie B. Sławeckiego:

Badacze mogą być wręcz całkowicie nieświadomi swojego uwikłania w ogólnie zaakceptowany system założeń filozoficznych i metodologicznych. Paradygmaty pozostają niekiedy głęboko ukryte, są milcząco zakładane i przez wielu traktowane jako oczywiste. Ponadto funkcjonowanie w ramach określonego paradygmatu zwalnia $\mathrm{z}$ konieczności rozważania założeń filozoficznych leżących u podstaw danego przedsięwzięcia naukowego, usprawiedliwia i legitymizuje jego inicjację i działanie. Jednak kiedy władza sądzenia o własnym postępowaniu pozostaje poza bezpośrednim zainteresowaniem bezrefleksyjnego wykonawcy projektów badawczych, to czy działalność naukowa pozbawiona tego krytycznego elementu różni się od pracy doradcy lub analityka? ${ }^{74}$.

Podobna refleksja towarzyszyła już wiele lat wcześniej rozważaniom Marii Łojewskiej: „naukowcy w czasie swej pracy badawczej abstrahują od przyjmowanych ogólnych założeń filozoficznych [...], nie zawsze są zainteresowani refleksją nad tymi założeniami, części mogą sobie nawet nie uświadamiać"75. Stwierdziła też: „Badacz jakiejkolwiek istniejącej dyscypliny zastaje wytworzoną przez innych wiedzę specjalistyczną i metody prowadzenia badań. I jakkolwiek nie musi się nad ich różnorakimi filozoficznymi podstawami świadomie zastanawiać, to posługując

72 J. Niżnik, op. cit., s. 150.

73 E. Guba, Y.S. Lincoln, op. cit., s. 282.

74 B. Sławecki, op. cit., s. 60.

75 M. Łojewska, Filozofia nauki i metodologia badań naukowych, Warszawa 1986, s. 16. 
się zdobytą wiedzą i metodami w swym dążeniu do stworzenia nowej wiedzy lub metod, przyjmuje wraz z nimi leżące u ich podstaw założenia"76.

Najważniejszą jednak sprawą, którą starano się tu wykazać, jest fakt, że za każdym mikrokrokiem w nauce, jak choćby jakościowe badania o małej skali, w które zaangażowano trzech naukowców i dziesięciu respondentów, stoją metateorie. Dzięki autorom tych metateorii - rozmaitym poglądom filozofów i ich kontynuatorów - kroki te są możliwe. Czy uznawane byłyby dziś w świecie nauki wyniki owych badań jakościowych i ich podejście humanistyczne, gdyby nie przełom antypozytywistyczny i jego inicjatorzy?

Istotny też jest fakt współistnienia, równorzędnego i równoległego funkcjonowania różnych, czasem całkowicie odmiennych paradygmatów w naukach społecznych. Dzięki temu, jak przez pryzmat, można przyglądać się danym zjawiskom społecznym z różnych punktów widzenia. Suma tych perspektyw daje pełniejszy obraz badanego zjawiska. Wyniki ilościowych i jakościowych badań czytelnictwa w Polsce ujęte razem dają dużo głębszy wgląd w tę działalność Polaków niż traktowane z osobna. Mogą (powinny) oddziaływać na siebie wzajemnie, np. wywiedziona przez badania jakościowe definicja e-czytania mogłaby zostać ujęta w kwestionariuszu pytań kolejnych planowanych badań jakościowych. O ile tylko autorzy obu podejść badawczych zechcieliby zaakceptować pierwiastek współpracy, czyli przyjąć... paradygmat superweniencji.

\section{Bibliografia}

Babbie E., Paradygmaty, teoria i badania społeczne, [w:] Podstawy badań społecznych, Warszawa 2008.

Bilicki T., Krytyka autorytetu w pedagogice radykalnego humanizmu Ericha Fromma, „Studia z Teorii Wychowania”, Warszawa 2011, t. 2, nr 1 (2).

Blackburn S., Oxfordzki słownik filozoficzny, Warszawa 1997.

Burrel G., Morgan G., Sociological Paradigms and Organizational Analysis, Londyn 1979, DOI: $10.2307 / 2392394$.

Cisek S., Filozoficzne aspekty informacji naukowej, Kraków 2002.

Condorcet A.N., Szkic obrazu postępu ducha ludzkiego poprzez dzieje, tłum. E. Hartleb, Warszawa 1957.

Didier J., Słownik filozofii, tłum. K. Jarosz, Katowice 1995.

Giddens A., Nowe zasady metody socjologicznej, Kraków 2009.

Grygrowski D., Zybert E., Bibliologia, biblioteki, bibliotekarze, Warszawa 2005.

${ }^{76}$ Ibidem, s. 17-18. 
Guba E.G., Lincoln Y.S., Kontrowersje wokół paradygmatów, sprzeczności i wyłaniające się zbieżności, [w:] Metody badań jakościowych, red. N. Denzin, Y.S. Lincoln, tłum. K. Podemski, Warszawa 2009.

Hałas E., Jakie nowe zasady metody socjologicznej? O wielości socjologii interpretacyjnych, [w:] $W$ kręu socjologii interpretatywnej - zastosowanie metod jakościowych, red. J. Leoński, A. Kołodziej-Durnaś, Szczecin 2005.

Heller M., Filozofia nauki, Kraków 2016.

Kaczmarek K., Paradygmat funkcjonalny Herberta Spencera, „Studia Socjologiczne” 2013, nr 2 (209), s. 32-46.

Karpiński A. J., Słownik pojęć filozoficzno-socjologicznych, Gdańsk 2006.

Kmita J., O kulturze symbolicznej, Warszawa 1982.

Koredczuk B., Początki teorii bibliologii, Wrocław 2005, DOI: https://doi.org/10.14746/b.2007.11.14.

Kuhn T.S., Struktura rewolucji naukowych, Warszawa 2009.

Lach E., Lévi-Strauss, tłum. P. Niklewicz, Warszawa 1998, DOI: http://dx.doi.org/10.1590/ S0104-93131998000200005.

Łojewska M., Filozofia nauki i metodologia badań naukowych, Warszawa 1986.

Migoń K., Bibliologia - nauka o kulturze książki, „Nauka” 2005, nr 2, s. 49-57.

Migoń K., Nauka o książce wśród innych nauk społecznych, Wrocław 1976.

Niżnik J., Idea paradygmatu w naukach społecznych, „Człowiek i Światopogląd” 1979, nr 1, s. $143-150$.

Popper K., Normal Science and its Dangers, [in:] Criticims and Growth of Knowledge, eds I. Lakatos, A. Musgrave, Cambridge 1970, DOI: https://doi.org/10.1017/ CBO9781139171434.007.

Skarga B., Kłopoty intelektu. Między Comte’em a Bergsonem, Warszawa 2017.

Skwarnicki M., Czytelnictwo i metody jego badania, [w:] Problemy czytelnictwa w wielkich miastach. Krajowa Konferencja Bibliotekarska $w$ Warszawie (2-4 czerwca 1958): referaty, przebieg obrad, red. S. Tazbir, Warszawa 1960.

Sławecki B., Paradygmaty w naukach społecznych, [w:] Badania jakościowe. Podejścia i teorie, red. D. Jemielniak, Warszawa 2012.

Socha I., Czytelnik w polskiej myśli bibliologicznej, [w:] Czytanie, czytelnictwo, czytelnik, red. A. Żbikowska-Migoń, współ. A. Łuszpak, Wrocław 2011, s. 25-44.

Szacki J., Historia myśli socjologicznej, Warszawa 2002.

Wajda A., Metodyka i organizacja czytelnictwa, Warszawa 1983.

Wendland M., Praktyki komunikacyjne jako praktyki społeczne w ujęciu historycznym, [w:] Historia idei komunikacji, red. M. Wendland, Poznań 2015, DOI: 10.15290/idea.2014.26.13, http://hdl.handle.net/11320/3208.

Wojciechowski J., Czytelnictwo, Kraków 2000. 